\title{
IMPACT OF REK BITOLA UPON PHYSICAL AND CHEMICAL PROPERTIES OF THE SOIL
}

\author{
Slobodan Bogoevski, Boško Boškovski, Gordana Ruseska \\ Faculty of Technology and Metallurgy, "Ss. Cyril and Methodius" University in Skopje, \\ Ruđer Bosković, 16, MK-1000, Skopje, Republic of North Macedonia \\ s.bogoevski@tmf.ukim.edu.mk
}

\begin{abstract}
A b s t r a c t: Contamination of soil by air sediment emitted from coal based thermal power plants is one of the basic ecological issue. The aim of this research is to define the impact of production of REK Bitola on the soils from defined microlocality in Pelagonia basin. Chemical, mineralogical and granulometric analyses were performed upon the soil samples. Also basic physical properties of the soil are determined. The chemical composition of the air sediment was also determined. According to the measured values and statistical data of REK Bitola, an average cumulative deposited quantity of air sediment is calculated, as well as the cumulative deposited quantity of trace elements in soil. The deposited air sediment has a negative impact on some of the basic physical and chemical properties of soil, but has no significant effect on the change in porosity and soil properties resulting from it.
\end{abstract}

Key words: REK Bitola; air sediment; soil properties

\section{ВЛИЈАНИЕ НА РЕК БИТОЛА ВРЗ ФИЗИЧКИТЕ И ХЕМИСКИТЕ КАРАКТЕРИСТИКИ НА ПОЧВАТА}

А п с т р а к т:- Контаминацијата на почвите со аероседимент емитиран од термоелектричните централи на јаглен е основен еколошки предизвик. Целта на ова истражување е да се дефинира влијанието на долгогодишното функционирање на РЕК Битола врз почвата на дефиниран микролокалитет во Пелагониската Котлина. Направени се гранулометриска, хемиска и минералошка анализа на почвата и се определени и нејзините основни физички параметри. На аероседиментот му е определен хемискиот состав. Според измерените вредности и статистичките податоци за РЕК Битола е пресметана просечната кумулативна депонирана количина на аероседиментот, како и кумулативната депонирана количина на микроелементи во почвата. Депонираниот аероседимент има негативно влијание и ги нарушува основните физички и хемиски процеси во почвата.

Клучни зборови: РЕК Битола; аероседимент; почвени карактеристики

\section{INTRODUCTION}

REK Bitola produces approximately $70 \%$ of the electric power in the state [1,2]. Thermal power plant was built near the coal deposits in Suvodol, Brod-Gneotino and Živojno. The location is $12 \mathrm{~km}$ eastern from Bitola (Figure 1).

Thermal power plant which burning coal has gas emission. This gas contain fly ash, and therefore is treated on electrostatic precipitator. The electrostatic precipitator in REK Bitola has efficiency of $99.84 \%$. Therefore $0.16 \%$ of fly ash is emitted in the atmosphere as air sediment $[1,2]$.
REK Bitola has installed measured instrument, which implementing 24 hours continual monitoring. Also emitted air sediment is controlled on the 3 measurement points near the thermal power plant, in Ribarci, Gneotino and Debalci [3, 4].

The altitude of $580 \mathrm{~m}$ and surrounding mountain impose temperate-continental climate. Average annual rainfalls are $610 \mathrm{~mm}$ [5]. According to Wind Rose the direction of blowing is N (189\%), NE (63\%), E (22\%o), SE (68\%o), S (134\%), SW (41\%), W $(61 \%)$ and NW (83\%). The circulation of air masses provides distribution and deposition of the air sediment on wide area. 


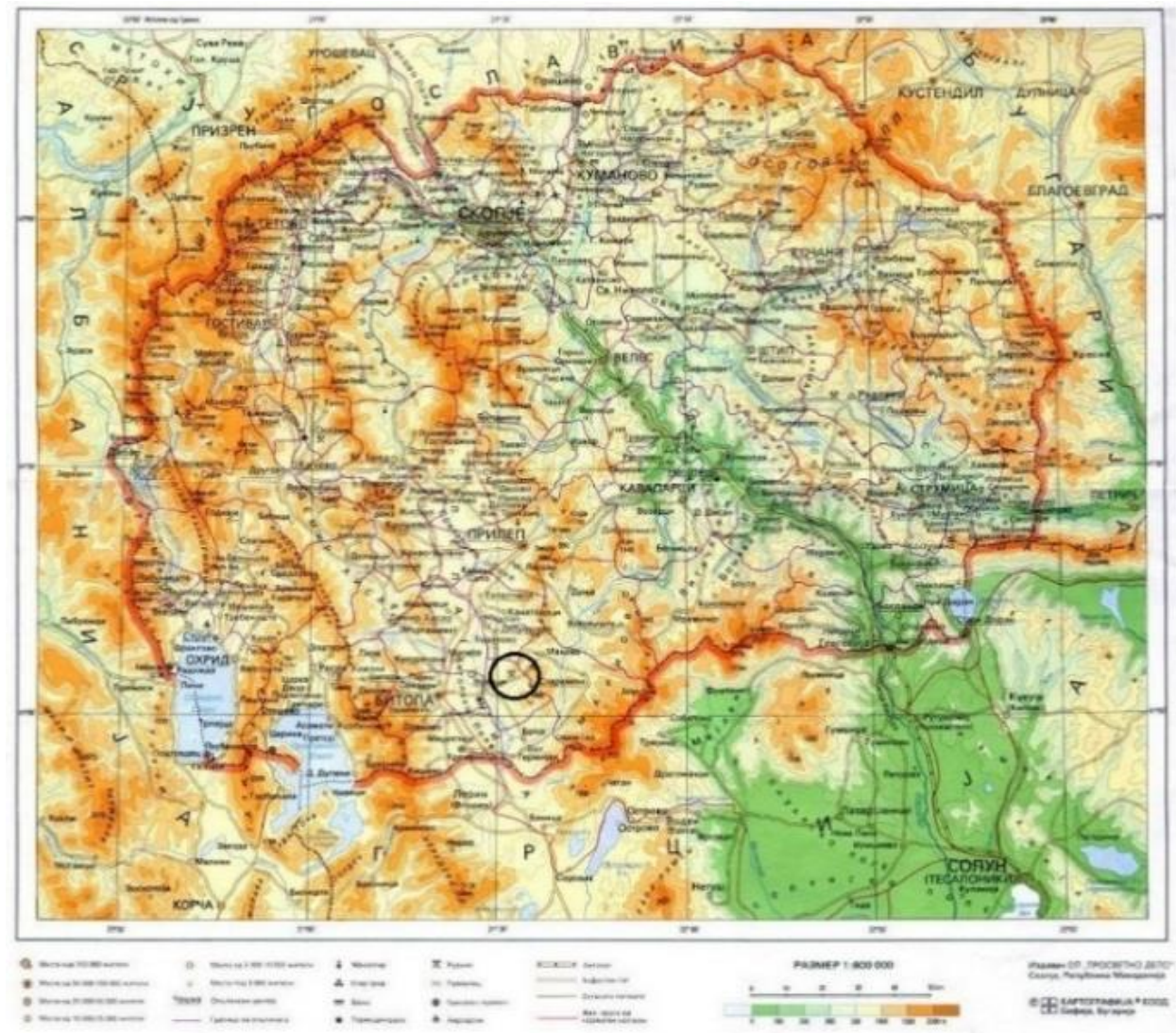

Fig. 1. Geographical map of the region

\section{EXPERIMENTAL}

In order to perceive the impact of REK Bitola on soils [6], is defined a microlocality around the thermal power plant with radius of $10 \mathrm{~km}$ (area of $3,14 \cdot 10^{8} \mathrm{~m}^{2}$ ), where the air sediment is deposited. There are defined 3 sample points I, II and III (Figure 2). From every sample point are collected cultivated (index 1) and uncultivated (index 2) soils for analysis.

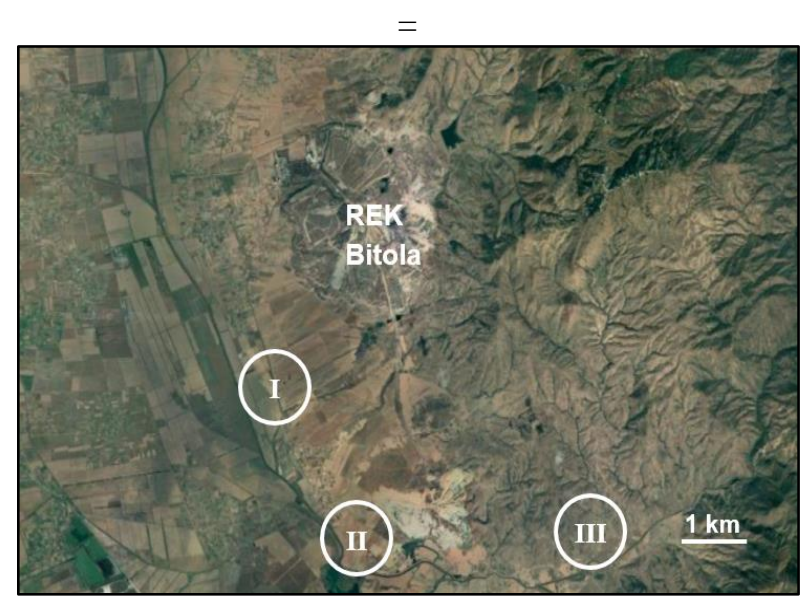

Fig. 2. Map of research area
Initially are determined the properties of the soils [7, 8]. In order to define granulometric composition of the soils [9], a wet sieve analysis has been realized. Chemical composition of the soil samples is determined by silicate chemical analysis. The existing minerals in soil have been identified by X-ray analysis, on Rigaku Ultima IV diffractometer [1017]. $\mathrm{pH}$ value of soil samples is measured from $30 \%$ water suspension on $\mathrm{pH}$ meter Sartorius.

The quantity of the deposited air sediment is determined applying gravimetric method according to the equation:

$$
X=\frac{m}{30 \cdot\left(r^{2} \cdot \pi\right)}-\left(\mathrm{mg} / \mathrm{m}^{2} \text { day }\right),
$$

where is:

$X$ - average daily quantity of air sediment, $\left(\mathrm{mg} / \mathrm{m}^{2}\right.$ day) ;

30 - number of days in month;-

$m$ - monthly quantity of air sediment (mg);

$r$ - radius of circle pan where the air sediment is deposited $(\mathrm{m})$.

Chemical composition of the deposited air sediment is also determined by silicate chemical analysis. Content of trace elements is determined by ICPAES analysis on spectrophotometer Varian 715-ES. 


\section{RESULTS AND DISCUSSION}

The mass contents of various dimensional fractions of grains are presented at Figure 3. From the histogram can be concluded that at all soil samples dominant with over $40 \%$ is fine fraction of grains $(-0.032 \mathrm{~mm})$. The other fractions have minimal contents, with exception of the dimensional fraction $(-0.25+0.1 \mathrm{~mm})$, which are in range of 12 to $20 \%$.

Chemical composition of the soil samples is presented in Table 1.

Dominant mass content has $\mathrm{SiO}_{2}$ with 67.86$69.13 \%$. The contents of $\mathrm{Al}_{2} \mathrm{O}_{3}$ are $11.74-12.37 \%$, and of $\mathrm{Fe}_{2} \mathrm{O}_{3}$ are $3.06-3.78 \%$. Soil contains of feldspars (XRD, Figure 4.), therefore in chemical composition are determined $\mathrm{Na}_{2} \mathrm{O}$ and $\mathrm{K}_{2} \mathrm{O} \cdot \mathrm{CaO}$ and $\mathrm{MgO}$ are from the existing carbonate minerals in soils. Chemical analyses indicate that the soils from this area of Pelagonia basin have relatively homogeneous composition. Because the soil samples are collected from points with minimal distance (under $5 \mathrm{~km}$ ) and have common pedogenesis, there is no significant variety. Consequently the material for X-ray examinations is collected as a composite sample from all soil sample points. From XRD (Figure 4) are determined minerals quartz, illite, Kfeldspar, Na-feldspar and calcite.

In the coarse fractions of grains dominant are quartz and feldspars (Figure 5).

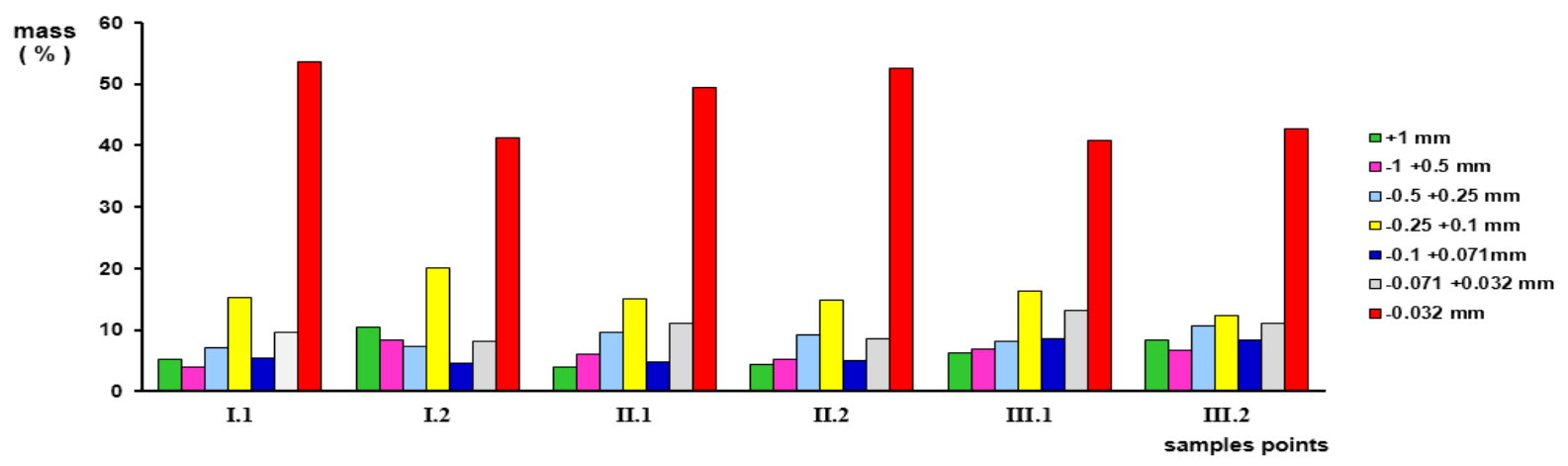

Fig. 3. Histogram of granulometric sieve analysis of the soils samples (mass \%)

Table 1

Chemical composition of the soils samples (mass \%)

\begin{tabular}{ccccccccccc}
\hline \hline & $\mathrm{SiO}_{2}$ & $\mathrm{Al}_{2} \mathrm{O}_{3}$ & $\mathrm{Fe}_{2} \mathrm{O}_{3}$ & $\mathrm{CaO}$ & $\mathrm{MgO}$ & $\mathrm{Na}_{2} \mathrm{O}$ & $\mathrm{K}_{2} \mathrm{O}$ & $\mathrm{SO}_{3}$ & $1 . \mathrm{w}$ & $\Sigma$ \\
\hline I.1 & 68.27 & 12.24 & 3.06 & 3.45 & 1.00 & 2.51 & 3.13 & 0.13 & 6.12 & 99.91 \\
$\mathrm{I} .2$ & 69.12 & 12.37 & 3.15 & 3.00 & 1.29 & 2.19 & 3.04 & 0.10 & 4.95 & 99.21 \\
II.1 & 67.86 & 11.87 & 3.78 & 3.57 & 1.14 & 2.29 & 2.85 & 0.15 & 6.34 & 99.85 \\
II.2 & 69.12 & 11.74 & 3.49 & 3.45 & 1.04 & 2.19 & 2.57 & 0.11 & 5.79 & 99.50 \\
III.1 & 68.52 & 12.23 & 3.21 & 3.60 & 1.15 & 1.80 & 2.57 & 0.09 & 6.51 & 99.68 \\
III.2 & 69.13 & 12.18 & 3.42 & 3.23 & 1.08 & 1.70 & 2.65 & 0.12 & 6.12 & 99.63 \\
\hline \hline
\end{tabular}

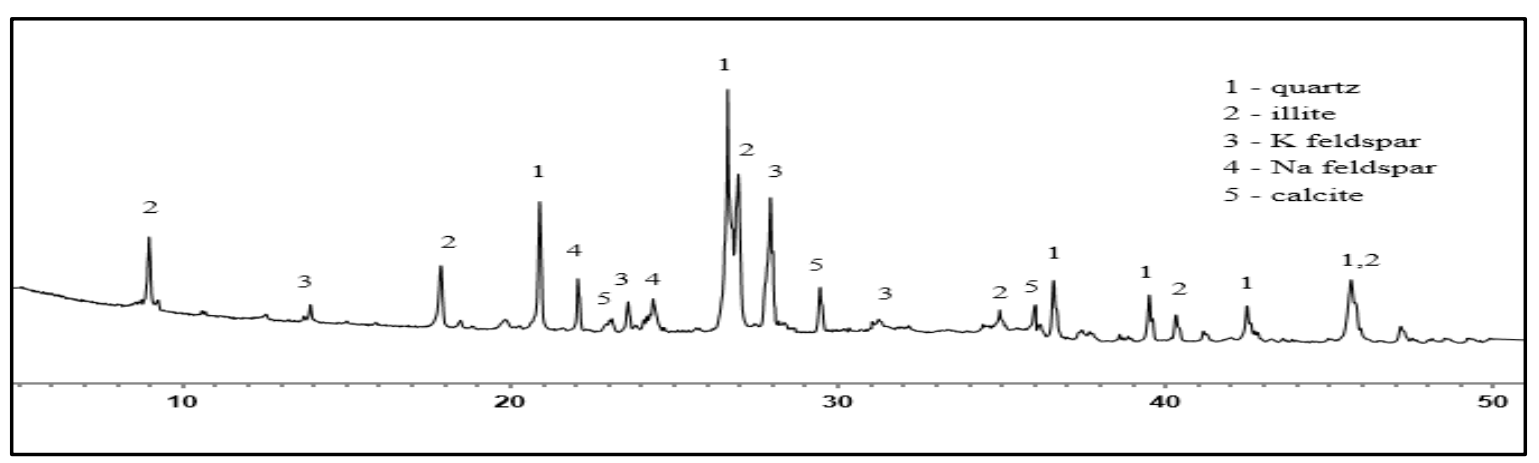

Fig. 4. XRD of the soil 


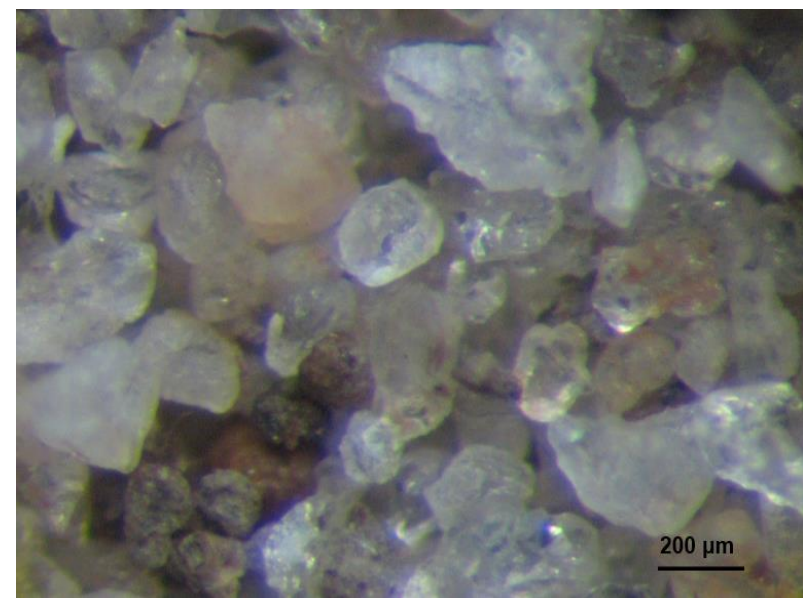

Fig. 5. Micrograph of dimensional fraction of grain $(-0.25+0.1 \mathrm{~mm})$ from soil sample I.1

The $\mathrm{pH}$ value of soil samples are slighty acidic in the range from 6.4 to 6.7 (Table 2).
Table 2

$p H$ values of soil samples

\begin{tabular}{lllllll}
\hline \hline Sample & I.1 & I.2 & II.1 & II.2 & III.1 & III.2 \\
\hline pH value & 6.6 & 6.4 & 6.7 & 6.5 & 6.6 & 6.7 \\
\hline \hline
\end{tabular}

Also some physical properties of the soil samples are determined (Table 3).

The air sediment particle size varies in a wide range from $1 \mu \mathrm{m}$ to over $10 \mu \mathrm{m}$ [18]. Chemical composition of the air sediment is in correlation with chemical composition of burning coal in REK Bitola [19-21]. The coal has lower degree of wood carbonization. Dominantly contains fine fraction of coal fragments, then fragments of coal clay and coal tailings [22, 23]. Chemical composition of the air sediment is presented in Table 4. Contents of trace elements are presented in Table 5.

Ta ble 3

Physical properties of the soil samples

\begin{tabular}{lcccccc}
\hline \hline & I.1 & I.2 & II.1 & II.2 & III.1 & III.2 \\
\hline Specific density $\left(\mathrm{g} / \mathrm{cm}^{3}\right)$ & 2.6658 & 2.6503 & 2.5989 & 2.6429 & 2.5351 & 2.6065 \\
Bulk density $\left(\mathrm{g} / \mathrm{cm}^{3}\right)$ & 1.5394 & 1.4281 & 1.5188 & 1.4994 & 1.4722 & 1.5181 \\
Porosity (\%) & 42 & 46 & 41 & 40 & 45 & 41 \\
\hline \hline
\end{tabular}

Table 4

Chemical composition of the air sediment (mass \%)

\begin{tabular}{lcccccccccc}
\hline \hline $\mathrm{SiO}_{2}$ & $\mathrm{Fe}_{2} \mathrm{O}_{3}$ & $\mathrm{Al}_{2} \mathrm{O}_{3}$ & $\mathrm{CaO}$ & $\mathrm{MgO}$ & $\mathrm{SO}_{3}$ & $\mathrm{P}_{2} \mathrm{O}_{5}$ & $\mathrm{TiO}_{2}$ & $\mathrm{Na}_{2} \mathrm{O}$ & $\mathrm{K}_{2} \mathrm{O}$ & $\Sigma$ \\
\hline 59.75 & 9.57 & 17.89 & 4.68 & 2.10 & 3.45 & 0.09 & 0.71 & 0.69 & 1.01 & 99.94 \\
\hline \hline
\end{tabular}

Table 5

Contents of trace elements in air sediment (ppm)

\begin{tabular}{cccccccc}
\hline \hline $\mathrm{Cd}$ & $\mathrm{Cr}$ & $\mathrm{Cu}$ & $\mathrm{Ni}$ & $\mathrm{Pb}$ & $\mathrm{Zn}$ & $\mathrm{Hg}$ & $\mathrm{As}$ \\
\hline 3.2 & 74.16 & 72.32 & 81.52 & 14.28 & 109.6 & 0.2 & 0.4 \\
\hline \hline
\end{tabular}

Approximately taking in consideration the constant production parameters of REK Bitola (coal, capacity and other), average years quantity of emitted air sediment is calculated. Average yearly requirement of REK Bitola is $6200000 \mathrm{t}$ of coal, which generate average $1114300 \mathrm{t}$ of ash. Consequently the average quantity of emitted air sediment $(0.16 \%)$ is $1782.88 \mathrm{t}[1,2]$. Until today, during 38 years (1982-2020) REK Bitola cumulative has emitted $67749.44 \mathrm{t}$ of air sediment. In relation with defined micro-locality of impact around the REK Bitola with radius of $10 \mathrm{~km}$ (area of $3,14 \cdot 10^{8} \mathrm{~m}^{2}$ ), calculated cumulative deposited quantity of air sediment on soil is $215.76 \mathrm{~g} / \mathrm{m}^{2}$. In relation with defined bulk density of the soils, cumulative deposited quantities of air sediment in various soil horizons are calculated (Table 6).

Acidic reaction of deposited air sediment reducing the $\mathrm{pH}$ value of the soil. As a consequence of that the biochemical processes in soil are disordered. Distributed air sediment reducing the soil porosity, which cause negative impact on soil water permeability.

In relation with defined chemical composition of air sediment, cumulative deposited quantities of trace elements in soil are calculated. In Tables 7-9 are presented cumulative deposited quantities of trace elements in various soil horizons. The quantity 
of the trace elements for all samples points is within the limited values [24]. With increasing of soil horizon depth, the quantity of pollutants in soil is reducing $[25,26]$.

Table 6

Cumulative deposited quantities of air sediment in various soil horizons $(\mathrm{g} / \mathrm{kg}$ )

\begin{tabular}{ccccccc}
\hline \hline Soil horizon depth $(\mathrm{cm})$ & I.1 & I.2 & II.1 & II.2 & III.1 & III.2 \\
\hline $0-10$ & 1.40159 & 1.51082 & 1.42060 & 1.43898 & 1.46556 & 1.42125 \\
$0-20$ & 0.70079 & 0.75541 & 0.71030 & 0.71949 & 0.73278 & 0.71063 \\
$0-30$ & 0.46715 & 0.50356 & 0.47348 & 0.47961 & 0.48847 & 0.47370 \\
$0-40$ & 0.35040 & 0.37770 & 0.35515 & 0.35974 & 0.36639 & 0.35531 \\
$0-50$ & 0.28032 & 0.30216 & 0.28412 & 0.28780 & 0.29311 & 0.28425 \\
$0-60$ & 0.23360 & 0.25180 & 0.23677 & 0.23983 & 0.24426 & 0.23688 \\
$0-70$ & 0.20023 & 0.21583 & 0.20294 & 0.20557 & 0.20937 & 0.20304 \\
$0-80$ & 0.17520 & 0.18885 & 0.17757 & 0.17987 & 0.18320 & 0.17766 \\
$0-90$ & 0.15573 & 0.16787 & 0.15784 & 0.15989 & 0.16284 & 0.15792 \\
$0-100$ & 0.14016 & 0.15108 & 0.14206 & 0.14390 & 0.14656 & 0.14213 \\
\hline \hline
\end{tabular}

Ta ble 7

Cumulative deposited quantities of trace elements (ppm) in soil horizon $0-10 \mathrm{~cm}$

\begin{tabular}{ccccccccc}
\hline \hline & I.1 & I.2 & II.1 & II.2 & III.1 & III.2 & \multicolumn{2}{c}{$\begin{array}{c}\text { Dutch standards list } \\
\text { Intervention }\end{array}$} \\
\hline $\mathbf{C d}$ & 0.00449 & 0.00483 & 0.00455 & 0.00460 & 0.00469 & 0.00455 & 0.8 & 12 \\
$\mathbf{C r}$ & 0.10394 & 0.11204 & 0.10535 & 0.10671 & 0.10869 & 0.10540 & 100 & 380 \\
$\mathbf{C u}$ & 0.10136 & 0.10926 & 0.10274 & 0.10407 & 0.10599 & 0.10278 & 36 & 190 \\
$\mathbf{N i}$ & 0.11426 & 0.12316 & 0.11581 & 0.11731 & 0.11947 & 0.11586 & 35 & 210 \\
$\mathbf{P b}$ & 0.02001 & 0.02157 & 0.02029 & 0.02055 & 0.02093 & 0.02030 & 85 & 530 \\
$\mathbf{Z n}$ & 0.15361 & 0.16559 & 0.15570 & 0.15771 & 0.16063 & 0.15577 & 140 & 720 \\
$\mathbf{H g}$ & 0.00028 & 0.00030 & 0.00028 & 0.00029 & 0.00029 & 0.00028 & 0.30 & 10 \\
$\mathbf{A s}$ & 0.00056 & 0.00060 & 0.00057 & 0.00058 & 0.00059 & 0.00057 & 29 & 55 \\
\hline \hline
\end{tabular}

Table 8

Cumulative deposited quantities of trace elements (ppm) in soil horizon 0-20 cm

\begin{tabular}{ccccccccc}
\hline \hline & I.1 & I.2 & II.1 & II.2 & III.1 & III.2 & \multicolumn{2}{c}{$\begin{array}{c}\text { Dutch standards list } \\
\text { Intervention }\end{array}$} \\
\hline $\mathbf{C d}$ & 0.00224 & 0.00242 & 0.00227 & 0.00230 & 0.00234 & 0.00227 & 0.8 & 12 \\
$\mathbf{C r}$ & 0.05197 & 0.05602 & 0.05268 & 0.05336 & 0.05434 & 0.05270 & 100 & 380 \\
$\mathbf{C u}$ & 0.05068 & 0.05463 & 0.05137 & 0.05203 & 0.05299 & 0.05139 & 36 & 190 \\
$\mathbf{N i}$ & 0.05713 & 0.06158 & 0.05790 & 0.05865 & 0.05974 & 0.05793 & 35 & 210 \\
$\mathbf{P b}$ & 0.01001 & 0.01079 & 0.01014 & 0.01027 & 0.01046 & 0.01015 & 85 & 530 \\
$\mathbf{Z n}$ & 0.07681 & 0.08279 & 0.07785 & 0.07886 & 0.08031 & 0.07789 & 140 & 720 \\
$\mathbf{H g}$ & 0.00014 & 0.00015 & 0.00014 & 0.00014 & 0.00015 & 0.00014 & 0.30 & 10 \\
$\mathbf{A s}$ & 0.00028 & 0.00030 & 0.00028 & 0.00029 & 0.00029 & 0.00028 & 29 & 55 \\
\hline \hline
\end{tabular}


Table 9

Cumulative deposited quantities of trace elements ( $\mathrm{ppm}$ ) in soil horizon $0-30 \mathrm{~cm}$

\begin{tabular}{ccccccccc}
\hline \hline & I.1 & I.2 & II.1 & II.2 & III.1 & III.2 & $\begin{array}{c}\text { Dutch standards list } \\
\text { Target }\end{array}$ & Intervention \\
\hline $\mathbf{C d}$ & 0.00149 & 0.00161 & 0.00152 & 0.00153 & 0.00156 & 0.00152 & 0.8 & 12 \\
$\mathbf{C r}$ & 0.03464 & 0.03734 & 0.03511 & 0.03557 & 0.03622 & 0.03513 & 100 & 380 \\
$\mathbf{C u}$ & 0.03378 & 0.03642 & 0.03424 & 0.03469 & 0.03533 & 0.03426 & 36 & 190 \\
$\mathbf{N i}$ & 0.03808 & 0.04105 & 0.03860 & 0.03910 & 0.03982 & 0.03862 & 35 & 210 \\
$\mathbf{P b}$ & 0.00667 & 0.00719 & 0.00676 & 0.00685 & 0.00698 & 0.00676 & 85 & 530 \\
$\mathbf{Z n}$ & 0.05120 & 0.05519 & 0.05189 & 0.05257 & 0.05354 & 0.05192 & 140 & 720 \\
$\mathbf{H g}$ & 0.00009 & 0.00010 & 0.00009 & 0.00010 & 0.00010 & 0.00009 & 0.30 & 10 \\
$\mathbf{A s}$ & 0.00019 & 0.00020 & 0.00019 & 0.00019 & 0.00020 & 0.00019 & 29 & 55 \\
\hline \hline
\end{tabular}

\section{CONCLUSION}

REK Bitola's production has the impact on the soil. Taking in consideration the air circulation in the Pelagonia basin and the properties of air sediment, is defined a microlocality of impact with radius of $10 \mathrm{~km}$ around the thermal power plant.

From 3 sample points in defined area, are collected soil samples for analysis. On soil samples are determinated granulometric composition, chemical composition, existing minerals, specific density, bulk density and porosity.

Also on air sediment is determined chemical composition. Taking in consideration the statistical data based on measured values of REK Bitola, calculated cumulative deposited quantity of air sediment in soil is $215.76 \mathrm{~g} / \mathrm{m}^{2}$. Also are calculated cumulative deposited quantity of the trace elements in various soil horizons, for all sample points. In surface soil horizon $0-10 \mathrm{~cm}$ the quantity of $\mathrm{Cd}$ was in the range from 0.00449 to $0.00483 \mathrm{ppm}, \mathrm{Cr}$ from 0.10394 to $0.11204 \mathrm{ppm}, \mathrm{Cu} 0.10136$ to 0.10926 ppm, Ni 0.11426 to $0.12316 \mathrm{ppm}, \mathrm{Pb}$ from 0.02001 to $0.02157 \mathrm{ppm}, \mathrm{Zn}$ from 0.15361 to $0.16559 \mathrm{ppm}$, $\mathrm{Hg}$ from 0.00028 to $0.00030 \mathrm{ppm}$ and As from 0.00056 to $0.00060 \mathrm{ppm}$. The content of pollutants is reducing with increasing of soil horizon depth.

Measured and calculated values of deposited quantity of air sediment in soils are compared with the values from Dutch National Standards for soil. The quantity of trace elements in soils are within the limited values, and is not a serious risk for human population. After finishing of defined producing period for REK Bitola (which is approximately 50 years), pollutants will going to be balanced in soil without repercussions for the environment. Deposited air sediment is reducing the $\mathrm{pH}$ value and porosity of the soil. This has negative impact on water permeability and biochemical processes of the soil.

\section{REFERENCES}

[1] Пецаков, С.: Основи на ексӣлоайација на енеріет̄ски блокови, ЈП „Електростопанство на Македонија“ Скопје, РЕК „Битола“ - Битола 1996.

[2] Пецаков, С.: Локална инсӣрукиија за ексйлоайаиија на иостиројки за хемиска йрийрема, ЈП „Електростопанство на Македонија“ - Скопје, РЕК „Битола“ - Битола, 1999.

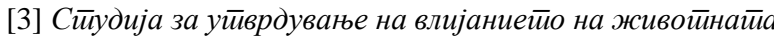

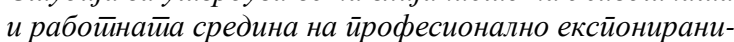

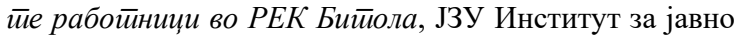
здравје на Република Македонија, 2010.

[4] Резулииайи од извршени мерена на емисиони йолуйан$\bar{u} и$ од Термоелекимранайа Бийола, Лабораторија за еколошки испитувања, Технолаб, Скопје, 2010, 11 $049 / 10$.

[5] Лазаревски, А.: Климайа во Македонија, Култура, Скопје, 1993.

[6] Pokale, W. K.: Effects of thermal power plant on environment, Scientific Rewievs \& Chemical Communications, 2 (3), 212-215 (2012).

[7] Nenadović, S., Kljajević, Lj., Nenedović, M., Milanović, M., Marković, S., Pavlović, V.: Physico-chemical soil analysis of Rudovci region, Geonauka, 1, (2) 1-8 (2013).

[8] Nenadović, S., Nenedović, M., Kljajević, Lj., Pavlović, V., Đorđević, A., Matović, B.: Structure and composition of soils, Processing and Application of Ceramics, 4 (4) 259 263 (2010).

[9] Balykov, B. I.: Granulometric composition of soil and its connection with standard distributions, Power Technology and Engineering, 36 (5) 289-294 (2002). 
[10] Galvão, L. S., Formaggio, A. R., Couto, E. G., Roberts, D. A.: Relationship between mineralogical and chemical composition of tropical soils and topography from hyperspectral remote sensing data, Journal of Photogrammetry and Remote Sensing, 63 (2), 259-271 (2008).

[11] Mata, J. F., Da Silva, R. R., Fontes, M. P. F., Erasmo, E. A. L., Farias, V. L. D. S.: Mineralogical, granulometrical, and chemical analysis in soils of ecotones of the southwest of Tocantins, Brasilian Journal of Applied Technology for Agricultural Science, 4 (2), 152-175 (2012).

[12] Shrivastava, V. S.: X-ray diffraction and mineralogical study of soil: A review, Journal of Applied Chemical Research, 9 (1) 41-51 (2000).

[13] Sonawane, D. S., Shrivastava, V. S.: X-ray diffraction and mineralogical study of Coastal soils and sediments, Asian Journal of Chemistry, 17 (1), 499-505 (2005).

[14] Reka, A. A., Pavlovski, B., Ademi, E., Jashari, A., Boev, B., Boev, I., Makreski, P.: Effect of thermal treatment of trepel at temperature range $800-1200{ }^{\circ} \mathrm{C}$, Open Chemistry, 17 (1), 1235-1243 (2019).

[15] Reka, A., Durmishi, B., Jashari, A., Pavlovski, B., Buxhaku, Nj., Durmishi, A.: Physical-chemical and mineralogical-petrographic examinations of trepel from Republic of Macedonia, IJISSET, 2 (1) 13-17 (2016).

[16] Reka, A.: Influence of mineralogical composition and microstructure of the binding material on the physico-mechanical properties of ceramic products obtained by hydrothermal process, $\mathrm{PhD}$ thesis, Faculty of Technology and Metallurgy, "Ss Cyril and Methodius" University in Skopje, 2004 (in Macedonian).

[17] Cekova, B., Pavlovski, B., Spasev, D., Reka, A.: Structural examinations of natural raw materials pumice and trepel from Republic of Macedonia, Proceedings of the $X V$ Balkan Mineral Processing Congress, Sozopol, Bulgaria, 73-75, 2013.
[18] Cvetković, Ž., Logar, M., Rosić, A., Ćirić, A.: Mineral composition of the airborne particles in the coal dust and fly ash of the Kolubara basin (Serbia), Journal of Mineralogy, Crystallography, Geochemistry, Ore Deposits, Petrology, Volcanology, 81 (2), 205-223 (2012).

[19] Ayanda, O. S., Fatoki, O. S., Adekola, F. A, Ximba, B. J.: Characterization of fly ash generated from Matla power station in Mpumalanga, South Afica, E-Journal of Chemistry, 9 (4), 1788-1795 (2012).

[20] Ismail, K. N., Hussin, K., Idris, M. S.: Physical, chemical \& mineralogical properties of fly ash, Journal of Nuclear and Related Technology, 4, 47-51 (2007).

[21] Sadasivan, S., Negi, B. S.: Chemical characterization of fly ash from coal-fired thermal power plants in India, Science of the Total Environment, 103 (2-3), 151-158 (1991).

[22] Извештај од испитување на физичко-хемиски карактеристики на јаглен РЕК „Битола“, Термоелектрана, Рударски институт, Белград, 2011, бр. 64/12.

[23] Pavlovski, B., Jančev, S., Petreski, Lj., Reka, A.: Bogoevski S., Boškovski, B.: Trepel-A peculiar sedimentary rock of biogenetic origin from the Suvodol village, Bitola, R. Macedonia, Geologica Macedonica, 25, (1), 67-72 (2011).

[24] Pančevski, Z., Stafilov, T., Bačeva, K.: Distibution of heavy metals in some vegetable grown in the vicinity of lead and zinc smelter plant, Contributions, Macedonian Academy of Sciense and Art, 35 (1), 25-36 (2014).

[25] Boškovski, B., Bogoevski, S., Stafilov, T., Ruseska, G., Kočuvoski, M.: Migration of arsenic and other microelements in anthropogenic contaminated soils, Mechanical Engeneering - Scientific Journal, 34 (1), 65-69 (2016).

[26] Belviso, C., Cavalcante, F., Di Gennaro, S., Palma, A., Ragone, P., Fiore, S.: Mobility of trace elements in fly ash and in zeolites coal fly ash, Fuel, 144 (15), 369-379 (2015). 
